\title{
SOUTH-SOUTH COOPERATION IN THE CHÁVEZ ERA IN VENEZUELA
}

\author{
J. Briceño-Ruiz
}

\author{
Cooperative University of Colombia, Bogotá, Colombia
}

\begin{abstract}
South-South Cooperation (SSC) has become one of the major trends in the International Relations of the new millennium. Initiatives of political cooperation, economic and technical assistance can be traced back to the 1960 's, for example the Bandung Conference of non-aligned countries or the creation of the United Nations Conference on Trade and Development (UNCTAD) under Raúl Prebisch's aegis [Braveboy-Wagner 2009; Prebisch 1954, 1969]. Nevertheless, the emergence of China and the BRICS and a new period of high oil prices have produced an increased involvement of middle-income states in initiatives of cooperation with other countries of the Global South.

Venezuela has been an actor in this wave of SSC during the government of Hugo Chávez. Certainly, SSC is not new in the Venezuelan external relations because Caracas implemented programs of cooperation to supply oil in special conditions to some Central American and Caribbean countries since the 1970's. Example of this were the Puerto Ordaz Agreement, approved during the Carlos Andrés Pérez administration (1974-1979) and the San José Agreement, a Venezuelan-Mexican initiative implemented in the early 1980's [Grayson 1985]. Similarly, Carlos Andrés Pérez played a role in the promotion of a New International Economic Order and in the establishment of the Latin American Economic System (known in Spanish as SELA) [Pérez 1980, 1983].

However, the logic of Venezuelan South - South cooperation was transformed since the rise to power of Chávez in 1999 and in particular after his victory in the recall referendum convened in 2004. Chávez aimed to transform the Venezuelan foreign policy since the beginning of his government. One of his goals was obviously the deepening of the relations with the Global South. Venezuela as a middle-income country became a driver in the new dynamics of SSC both in Latin America and the Caribbean and beyond the Western Hemisphere.

This paper analyses this increasing involvement of Venezuela in initiatives of SCC, in particular the reasons that led Chávez to promote those initiatives. Due to the particular narrative furthered by the Venezuelan government to explain its SSC agenda, supposedly based on solidarity, complementarity and cooperation, this paper compares Venezuelan strategy of international cooperation with more traditional forms of North-South Cooperation (NSC). To achieve such a goal, a qualitative methodology is used in the paper based on the review of the literature on international cooperation and on the evaluation of international cooperation promoted by the Venezuelan government.
\end{abstract}

Key words: South—South cooperation (SSC), Hugo Chávez, Venezuela, the "Bolivarian revolution", oil diplomacy

\section{MODALITIES AND REASONS OF SOUTH-SOUTH COOPERATION}

Liberal theory has associated the emergence of an interdependent world to the need for cooperation and the creation of international regimes [Keohane 1984]. By contrast, realists argue that liberal optimism on international cooperation has proved to be wrong due to the perennial impact of anarchy on the behavior of states [Axelrod 1984; Grieco 1991]. Cooperation in this logic refers to a kind of state behavior in areas where 
potential common interests exist, such as finances, trade or communications. However, cooperation has another meaning, in particular in the Development Studies. Thus, cooperation refers to diverse programs furthered by developed countries to assist developing world in the context of the postwar era. Cooperation was understood mainly as foreign aid, development assistance, technical assistance or technical cooperation. Behind all these notions was the key idea of transfers of funds from the Northern developed countries to foster economic development and social progress in the Southern developing countries. Thus, international cooperation was linked to economic development and was mainly North-South oriented.

The United Nations played a crucial role in this process by implementing programs of technical assistance since 1948. Beyond the UN, developed countries also created their own programs labelled as Official Development Assistance (ODA) and national agencies to manage foreign assistance, the best known of which is the United States Agency for International Development (USAID). Developed countries decided to create a common framework within the Organization of European Economic Cooperation (OEEC) to deal with aid and assistance to the Third World countries. A Development Assistance Group (DAG) was created in 1960 within the OEEC, and when the OEEC was transformed in the Organization of Economic Cooperation and Development (OECD) in 1961, the DAG became Development Assistance Committee (DAC).

Nevertheless, the decolonization in Africa and Asia led to new interpretations of economic development, cooperation and aid. The paramount moment of this process was the Summit of Bandung (1955), when 25 Asian and African countries met to create mechanisms to coordinate their interests and strengthening their position vis-à-vis industrialized countries [De Renzio, Seifert 2014: 1862]. Very soon in 1961 in Belgrade there was created the Non-Aligned Movement (NAM). As a result of these events, a new narrative challenged the postwar hegemonic view on international cooperation that had been associated almost exclusively to economic development and modernization. After Bandung and Belgrade, cooperation took on a political dimension and began to be also treated as "coalition building" among the Third World countries, particularly in multilateral institutions [Lecchini 2012: 12]. The creation of the G77 in 1964 demonstrated the trend. This approach to international cooperation led to the creation of the Organization of Exporting Petroleum Countries (OPEC) in 1960. Further events such as the establishment of UNCTAD, the proposal of creating of New International Economic Order (1974) or the Buenos-Aires Plan of Action on South-South Cooperation (1978) were the natural dvelopment of the process initiated in Bandung.

These innovative multilateral initiatives were accompanied by concrete bilateral actions of economic cooperation implemented by Thailand, China and India, countries that in the 1960's began to develop programs outside the schema advocated by the OECD-ODA. The rise of emerging economies in the new millennium, in particular China, led to a relaunch to bilateral programs of cooperation. The so-called BRICS (Brazil, Russia, India, China and South Africa) have played a crucial role in the new momentum of the SSC in the last two decades. Moreover, other middle-income countries such as Saudi Arabia, Qatar and Venezuela implemented programs of cooperation with the Global South. 
Thus, after seven decades since the first initiatives of technical assistance in the UN, the current scenario is quite diverse. On the one hand, one observes the traditional OECD-ODA NSC that still represents the largest amount of global assistance and, on the other hand, Global South emerging actors are furthering modalities of SSC. One can even perceive some forms of triangular cooperation in which traditional and emerging donors are involved. In this scenario, questions arise on the nature of these diverse modalities of cooperation, in particular on how they work and the extent to which they are compatible. Another crucial question is related to the reasons behind the SSC initiatives: are they different from to those argued by traditional OECD-ODA donors?

NSC and SSC are slightly different. The OECD-ODA's narrative on cooperation is related to foreign aid or economic assistance to development. Conversely, SSC is often described a multidimensional because of the political, technical and economic objectives to be achieved. The political dimension of cooperation refers to the creation of multilateral or regional forums among developing countries to improve coordination and their bargaining power vis-à-vis the developed countries [Lecchini 2012]. The technical dimension or technical cooperation is "essentially a process whereby two or more developing countries pursue their individual or collective development through cooperative exchanges of knowledge, skills, resources and technical know-how" [Revised Guidelines for the Review... 2003: 4]. The economic dimension of cooperation refers to the promotion of closer relations in trade, finance, investments and social policy. Even technical and economic dimension contrasts from the traditional ODA's view on economic assistance because SSC cooperation involves "different and evolving forms, including the sharing of knowledge and experience, training, technology transfer, financial and monetary cooperation and in-kind contribution" [What is South-South Cooperation 2015].

SSC would differ from NSC not just in terms of the practice of cooperation but also on the principles in which would be based on. Thus, SSC would aim at ascertain principles such as horizontality, consensus and equity. Horizontality means that cooperation is developed among countries that perceive each other as partners. In consequence, cooperation should be voluntary and untied to a compromise to buy goods and services from the donor. Consensus implies a common framework to negotiate and manage cooperation. Finally, equity indicates that benefits and costs derived from cooperation should be shared among the partners.

The dichotomy NSC and SSC evidences the diversity of logics of associative relations in the international system. None of them could pretend to have a moral superiority over the other. However, the alleged innovative principles and practices of SSC could lead to argue that the reasons of emerging powers or middle-income countries to promote it are different from those one of developed states. This is a crucial issue when analyzing SSC and the strategies followed by countries such as Venezuela help to understand the issue.

Studies on foreign aid promoted in the OECD-ODA perceives two kinds of reasons to foster it: humanitarians and self-interest. For pundits such as Lumsdaine [Lumsdaine 1993], aid is given basically due to ethical and moral concerns related to the 
fight against global poverty. Thus, "there has been an extended argument that it is the moral responsibility of rich countries to assist in reducing poverty and enhancing economic development in poor countries, over and above any considerations of selfinterest" [Ruttan 1989: 415]. This narrative subscribes to the liberal tradition, that treats aid as "as an instrument or reflection of the tendency of states to cooperate in addressing problems of interdependence and globalization" [Lancaster 2007: 4]. Aid would be "a moral action that embodied a vision of international peace and prosperity" [Hattori 2003: 229]; a moral action the inhabitants of developed countries have "to assist the inhabitants of the poor countries by transferring resources to them" [Opeskin 1996: 21].

Foreign aid is perceived in another narrative on the issue as a donor countries' strategy to promote their political and economic interests. A political explanation considers aid as a component of the donor's foreign policy. Hans Morgenthau [Morgenthau 1962] and George Kennan [Kennan 1971], founders of the classical realism theory, considered that political and strategic imperatives and not altruism were the reasons behind cooperation with developing countries. In Carol Lancaster's words: "...aid (for purposes other than humanitarian relief) began as a temporary expedient of Cold War diplomacy... If there had been no Cold War threat, the United States - the first and, for most years, the largest aid-giving country — might never have initiated programs of aid or put pressure on other governments" [Lancaster 2007: 5]. The economic explanation considers that aid "constitutes a part of donor nations' commercial strategy to secure a larger trade benefits... Donors also use aid as an instrument for improving goodwill while expecting that recipients will reciprocate by buying more of their products" [Younas 2008: 662]. Younas argues that aid may also be given as a reward to the recipient nations for promoting imports and removing trade restrictions. This implies that donors can influence recipients to get preferential treatment on the goods imported from them without entering formal trade agreements [Younas 2008: 662].

In contrast, SSC would not be based on economic or political self-interest. SSC would be based on mutual benefits among the countries. SSC would be based on postcolonial solidarity and non-conditionality and it implies the share of expertise "based on direct experience of pursuing development in a poor country circumstances" [Mawdsley 2012: 264].

However, the claim of solidarity as the motivation of the SCC is contested. SSC is also promoted because of political and strategic reasons. From the Bandung Summit to the BRICS, SSC has been associated to goals such as the increase of bargaining power, the reform of global institutions, the democratization of international relations and the challenge of Northern hegemony. Certainly, the logic and instruments of SSC, for example non-intervention, respect to sovereignty and non-reciprocity, are different from those of NSC. This notwithstanding, if the SSC's logic of implementation differs from the NSC's one, the political and strategic motivations do not. Benzi and Zapata assert that the experiences of SSC "unequivocally suggest that the direct and symbiotic relationship between aid, foreign policy and security, trade and economic interests and power projection inherent to the North South Cooperation also exists in the case of South-South [cooperation]" [Benzi, Zapata Mafla 2013: 68]. 
The extension of this paper does not allow in-depth analysis of the diverse views about the similarities and differences between NSC and SSC. Nevertheless, the case of Venezuela in the Chávez era is an excellent case to evaluate the logic of SSC and the reasons behind it. One argues in this paper that the Venezuelan initiatives of SSC cannot be understood and explained without considering their relation with the foreign policy and the narratives and interests furthered by the so-called Bolivarian revolution.

\section{VENEZUELA AND SSC UNDER THE CHÁVEZ AEGIS ${ }^{1}$}

International cooperation is not something new in the Venezuelan foreign policy ${ }^{2}$. Manuel Pérez Guerrero (1911 - 1985), a close collaborator of presidents Romulo Betancourt and Carlos André Pérez, was a figure in the development of SSC initiative since the 1960s. He was one of the inspirers of the Organization of United Nations Educational, Scientific and Cultural Organization (UNESCO), and served as the first executive secretary of the Technical Assistance Committee Developing Countries of the United Nations. He was elected president of the Economic and Social Council of the United Nations (ECOSOC) for the period 1967-1969 and became later Secretary of the Conference of the Nations United Nations on Trade and Development (UNCTAD) between 1969 and 1974 as successor to Raúl Prebisch. He promoted the creation of Generalized System of Preferences and the approval of the Least Developed Countries category (LDC).

Caribbean Basin was the preferential area where Caracas developed cooperation. Rafael Caldera promoted closer relations with the English-Speaking Caribbean during his administration (1964). His Minister of Foreign Affairs Aristides Calvani was an enthusiastic promoter of a rapprochement to the Caribbean, a region considered of strategic importance for Venezuela. Carlos Andrés Pérez signed the Puerto Ordaz Agreement in 1976 and Luis Herrera Campins subscribed the San José Agreement (1980). The Puerto Ordaz agreement allowed Venezuela to sell oil in special conditions to Caribbean islands, countries on which the Venezuelan government led by Pérez aimed to have a political influence. The San José Agreement was also a program of cooperation in the field of energy, developed in collaboration with México that sold oil in special condition to some Caribbean and Central American countries. Both Puerto Ordaz Agreement and San José Agreement sought to the projection of the Venezuelan interests and narratives in the Caribbean Basin. In a context of decolonization of the Caribbean islands, revolutionary civil war in Central America and the expansion of Cuban influence in the region (even in Venezuelan neighbors such as Grenada and Guyana) in the

1 The two following sections of this paper are based on the paper "Venezuela and South-South Cooperation: Solidarity or Realpolitik?" published in South-South Cooperation Beyond the Myths Rising Donors, New Aid Practices? edited by I. Bergamaschi, P. Moore and A.B. Tickner.

2 On the evolution of Venezuelan from 1958 to nowadays, see: [Romero 2003, 2010; Romero, Curiel 2009; Corrales 2009; Clem, Maingot 2011; Briceño-Ruiz 2011; Serbin y Serbin Pont 2014; Romero, Mijares 2016]. For Russian views on the issue, see: [Dabagyan 2012, 2014], Rosenthal, D. (2013). Caracas y Washington: las relaciones en el fondo de la crisis política en Venezuela. Paper presented at the International Forum "Russia and Iberoamerica in a globalizing world: history and modernity", St. Petersburg, Russia, 26-28 September 2013. 
1970's and early 1980's, President Pérez used oil diplomacy as a mechanism to promote the national interest. Cooperation was linked to the narrative of defense of democracy that was considered a Venezuelan foreign policy goal. Behind this, the interest was to preserve the stability of a region that was crucial for the Venezuelan national security and even for its economy because the Caribbean Sea was the major trade route of the Venezuelan oil exports. Thus, those initiatives used oil as a foreign policy tool, a reason that allowed arguing that Carlos Andrés Pérez was the initiator of the so-called oil diplomacy that used oil as an instrument to promote the international projection of Venezuela.

Beyond the Caribbean, Venezuela was founder of the Organization of Petroleum Exporting Countries and it was member of UNCTAD since its early years in 1960's. The country became a member of the Non-Aligned Movement in 1974 and Pérez was a promoter of the North-South Dialogue [Pérez 1980]. This was a policy initially promoted by the Social Democratic party Acción Democrática (AD) and it was continued by Christian Democrat party COPEI. Venezuela played a crucial role in the foundation of OPEC, one of the promoter was Juan Pablo Pérez Alfonso. As known, OPEC became a crucial player in the determination of oil prices since the 1970's onwards. Venezuela was also a player at UNCTAD and during the Pérez administration backed initiatives such as the creation of a New International Economic Order (NIEO), a goal promoted by the so-called Third World in those days [Pérez 1977]. Pérez also fostered closer relations with African countries (it was well-known his friendship with Tanzanian President Julius Nyerere) and with the European social democracy. Thus, it is also valid to argue that the first attempt to promote Venezuela as a leading actor was developed by Carlos Andrés Pérez in the 1970's.

This is also valid at Latin American level. Pérez was a promoter of SELA in 1976, in collaboration with Méxican President Juan Martín Echeverría. SELA was an important initiative in 1970's. The Organization of American States (OAS), created in 1948, had been the regional framework for political dialogue, collaboration and cooperation among the Latin American countries. However, OAS was not a Latin American institution but a Western Hemispheric one in which the United States played a hegemonic role. By contrast, SELA was conceived an "exclusive Latin American" space, in which the Latin American countries could discuss their regional affairs without the US intervention. Even if soft, SELA was a challenge to the US in the region [Maldonado-L 1982; Salazar Santos 1985].

Therefore, the Venezuelan foreign policy previous to rise to power of Hugo Chávez included consistent and coherent initiatives to promote SSC. President Pérez granted particular importance to those initiatives, particularly in the Caribbean Basin, but also beyond that region. He was the initiator of the Venezuelan oil diplomacy and he made the initial effort to promote policies leading to make Venezuela a true global actor. However, those policies were mainly autonomist, as proposed by the academic Juan Carlos Puig [Puig 1980] and Helio Jaguaribe [Jaguaribe 1979]. They not aimed at a rupture with the capitalist international order or a permanent conflict with the United States but an increasing autonomy for the Third World countries. Similarly, the initiatives of SSC 
were closely related to the defense of democracy, a goal promoted by one of the few democracies in the region for the time.

The new foreign policy aimed at producing a rupture with some aspects of that promoted in the 1970's and 1980's. New premises were established: a) the promotion of a multipolar world; b) the "Bolivarian" ideal of regionalism; c) the fight against neo-liberalism and d) the strengthening of South-South cooperation.

Chavez strongly highlighted the need for a multipolar world, what in reality meant the rejection of the post-Cold War global order that had initially been based on the US unipolarism. For Chávez, this situation had produced a power imbalance in the international system and, in consequence, "alternative poles of power" should be created to restore balance. The promotion of a multipolar world led to foster "an independent foreign policy", manifested in closer relations with countries such as Cuba, China, Brazil, Iran and Russia, with the goal of promoting alternative poles to unipolarism. Venezuela also promoted what Chávez called 'the Bolivarian dream to constitute a great Confederation of racially mixed nations', or the "Bolivarian integration". This strategy excluded the United States, as expressed in the radical opposition to the proposal of establishing a Free Trade Area of the Americas (FTAA) [Briceño-Ruiz 2006]. The fight against neo-liberalism became also a foreign policy goal. Chávez rejected the adoption of neoliberal policies at domestic level but also criticized the way as neo-liberalism had influenced the so-called new regionalism in the Americas.

The agenda stressed another issue, closely related to the fight against unipolarism, the promotion of South-South cooperation. The Venezuelan diplomacy initially intended reactivating mechanisms of cooperation among developing nations, such as the Non-Aligned Movement and the Group of Rio. Venezuela also participated in the creation of G20, a group of underdevelopment countries generated at the World Trade Organization Trade Ministerial Meeting held in Cancun, Mexico, in November 2003.

A key element of this strategy was the "oil diplomacy" that had a two-fold dimension. The first one was global: the restoration of the role of OPEC in the determination of oil prices, as exemplified in the convening of an OPEC Summit of Heads of State in 2000, in Caracas. The second dimension was the use of oil as a mechanism to promote SSC. Venezuela had sold oil in special conditions to Central American and Caribbean since the early 1980, but in the era of Chávez new initiatives were set up to incorporate Cuba, Uruguay, Paraguay and Argentina. Similarly, Venezuela promoted join ventures with Brazil, Uruguay and Cuba, where were projected the building of refineries. Moreover, Chávez promoted the creation of a South American pipeline to send gas from Venezuela to Argentina. All these initiatives were part of more global proposals such as Petrocaribe or Petroamérica. Another innovative aspect of the SSC strategy was concrete actions of financial aid and technical assistance, sometimes as donor, other times a recipient, with China, Russia, Belorussia, Iran and some African countries [Briceño-Ruiz 2006].

After 2004, the Venezuelan foreign policy was radicalized. Thus, the narrative based on a criticism of unipolarism was transformed into anti-imperialism. Similarly, after the adoption of the 21 st Century Socialism, the anti-capitalist discourse complemented 
the criticism to neo-liberalism. At that moment, the problem for Chávez was not a particular way to understand capitalism (the neo-liberalism), but the capitalist system itself.

In this context, SSC and the promotion of initiatives of regional integration in Latin America became fundamental goals in the Venezuelan international strategy. Favorable conditions created by high oil prices allowed Chávez to create new programs and initiatives in Latin America and the Caribbean and in the other regions of the Global South, particularly in Africa. Venezuelan actions of SSC included political, technical and economic cooperation.

The political cooperation is related to the aim of achieving a multipolar world. In the case of Latin America and the Caribbean, Chávez became a leader in the promotion of regional initiatives of political dialogue and cooperation such as UNASUR and CELAC. ALBA was also an instrument of political cooperation in which Venezuela has had a hegemonic role. While the ideological diversity in UNASUR and CELAC led in many occasions to political compromises based on a minimum common denominator, the ideological uniformity in ALBA allowed adopting policies that fully coincided with the Venezuelan foreign policy objectives. ALBA is a multidimensional process. Born as a Venezuelan alternative to the FTAA in December 2001, ALBA became a regional space after the signing of the Havana agreements in December 2004. Thus, ALBA is a process of regional cooperation in the social and economic spheres. At the same time, it has developed mechanisms of economic integration but, at least in the view of the promoters of this regional initiative, based on cooperation, solidarity and complementarity. This is the reason why it is described in the official documents of its member countries as a new model of regional integration. Finally, ALBA was conceived as an instrument of political cooperation to establish a multipolar world and foster antiimperialism ${ }^{3}$.

The second dimension of Venezuelan actions is technical cooperation. Venezuela strengthened the technical cooperation with Argentina, Brazil, Uruguay and Cuba in sectors such as health, agriculture and agro-food, environment, energy, education, among others. In the oil industry, Venezuela provided technical assistance to Ecuador in oil refining and Bolivia in the production of gas.

In the field of economic cooperation, Venezuela developed cooperation in social programs, finance and energy with the Caribbean and Latin American countries.

The "internationalization of the Misiones", namely, the implementation of social programs in certain Latin American and Caribbean countries, mostly members of ALBA, was crucial in the Venezuelan strategy. Misiones was the name given to the social programs in the field of health and education implemented in Venezuela since 2004. Misión Milagro provided free medical attention and free eyes surgery to low-income people from Latin America and the Caribbean countries. Another social program was the Misión Yo si Puedo (Yes I can), a program also managed by Cuban specialists, the goal of which is to teach to illiterates to read.

3 On the evolution of ALBA, see: [Briceño-Ruiz 2011, 2014, 2015; Bagley \& Defort 2015; Cusak 2015; Benzi 2016]. 
The financial cooperation aims at creating mechanisms to diminish the Latin American and Caribbean dependence on multilateral financial institutions, such as the International Monetary Fund (IMF) and the World Bank (WB). Examples of this are the Bank of the South, formally set up in December 2007 and the ALBA Bank, created in 2008. However, these initiatives were not actually implemented. The agreement that created the Bank of the South was approved in 2007. This was conceived as a mechanism to finance developmental initiatives in South America but the agreement was not ratified by countries such as Brazil and other states such as Colombia, Chile and Peru did not participate in this initiative. The ALBA Bank was not properly an institution to deal with financial crisis but a source of resources to pay projects in areas such as health, education, energy in the Caribbean Basin. The financial dimension was developed mostly at bilateral level. Thus, Venezuela provided 8.6 billion of US dollars in financing to Argentina between 2005 and 2008 by underwriting its sovereign bonds. Venezuela also purchased \$300 million in Ecuadorean sovereign bonds in 2005 and \$100 million in Paraguay debt in 2007 [Labaqui 2014: 38].

Petrocaribe was the major Venezuelan program in the sector of energy cooperation. The program was created in 2005 as an extension of the Caracas Energy Agreement subscribed in 2000. According to Benzi and Zapata [Benzi, Zapata Mafla 2013: 76], Petrocaribe has at least four dimensions: 1) a financing scheme of part of the energy bill of the member countries; 2) measures to reduce intermediate and transport trade costs of oil and its derived products; 3) a social development fund; 4) the promotion of energy efficiency. Petrocaribe is closely related to the ALBA project.

Chávez also promoted SSC initiatives with Africa in the fields of political, technical and economic cooperation.

In the field of political cooperation, the establishment of diplomatic relations with some countries was followed by the interest in participating in regional spaces in the African continent. Thus, Venezuela became observer of organizations such as the African Union (2005), the League of Arab States (which includes 10 African countries) in 2006, The Economic Community of Western African States (ECOWAS) in 2009 and the Southern African Development Community (SADC) in 2009 [Mata Carnevali 2012b: 21]. Chávez participated in the Summits of the African Union held in Banjul (2006). He also visited Gambia, Mali, Benin, Angola, South Africa, Algeria and Libya [Mata Carnevali 2012b: 21].

The promotion of the Africa - South American Summits (ASA) - was a key element in the Venezuelan strategy. Certainly, ASA was an idea of Presidents of Nigeria, Olusegun Obasanjo, and Brazil, Luiz Inácio (Lula) da Silva in 2005, but Chávez subscribed to it and became a main promoter of the creation of a mechanism of political dialogue between Africa and South America. As a result, the second ASA summit was held in Margarita Island, Venezuela, in September 2009, with the presence of 30 leaders of both regions. The summit was an opportunity for Chávez to present his view of the international system and the role peripheral regions such as South America and Africa should play, and in particular he highlighted the urgent task of constructing the multipolar world [Chávez Frías 2009]. 
SSC has also been developed in the sphere of technical cooperation. Thus, around 350 African students from 20 African countries (Angola, Benin, Cape Verde, Ethiopia, Gambia, Ghana, Equatorial Guinea, Guinea-Bissau, Kenya, Libya, Mali, Mozambique, Namibia, Nigeria, Western Sahara, Sao Tomé and Principe, Senegal, Seychelles, Sierra Leone and Togo) have studied medicine and social sciences in Venezuela. Moreover, more than 100 Venezuelan technicians have gone to Algeria and Egypt to specialize in the energy sector [Mata Carnevali 2012b: 22].

The Venezuelan economic cooperation in Africa involves mainly social programs in the area both of health and education. The program Adopta una escuela en Africa (Adopt a school in Africa), was launched in 2007 and has been implemented in 16 African countries. According to the Vice-Ministry of Africa, the initiative has reached about 70000 school-age infants. Adopta una escuela en África is a program of assistance through which the Venezuelan embassies provided financial assistance to school with shortages, by providing school supplies and helping with the repairs and maintenance of their buildings [Giacchi 2012: 54]. The cooperation in health implied medical attention to African children with severe heart diseases at the Pediatrics Hospital Dr. Gilberto Rodriguez Ochoa in Caracas [Mata Carnevali 2012b: 21].

\section{EVALUATING THE LOGIC OF THE VENEZUELAN SSC: SOLIDARITY OR REALPOLITIK}

The Venezuelan government narrative highlights that the initiatives of SSC towards Latin American and the Caribbean and Africa are not based on the traditional logic of self-interest, especially in the sphere of trade and investments. In contrast to the logic of benefits implicit in the NSC programs, Venezuela would be promoting new forms of associative relations based on solidarity, complementation and mutual understanding. These principles would be the driven forces of schemes of regional integration such as ALBA or cooperation initiatives such as Petrocaribe, Yo si puedo, Misión Milagro or Adopta una Escuela en África. No economic or trade compensation would be behind these initiatives but a genuine interest in promoting links with countries that experienced similar histories of colonization and imperialism. Similarly, the Venezuelan narrative also excludes any sort of altruism behind its SSC initiatives but the idea of mutual benefits with countries that could also help Venezuela to overcome some of its economic or social problems. Thus, the principles of horizontality, consensus and equity would inspire the Venezuela actions of SSC.

However, as Daniel Hellinger [Hellinger 2011: 57] argues 'Venezuelan influence comes from both soft and hard power. Its soft power is ideological, stemming from the public rhetoric of Hugo Chávez and the relative success of its domestic model in achieving democracy as well as economic and human development. Its hard power comes mainly in the form of oil diplomacy'. Arguably, the rhetoric on a SSC based on solidarity, complementary, equity and consensus was a deployment of the Venezuela's soft power in Africa, Latin America and the Caribbean. Thus, Venezuela presented itself at the regional and global scenario as a country that shared the benefits of the 'oil boom' through a generous policy of cooperation with countries that would have serious financial problems if they had to pay oil at international prices. 
The hard power, namely, the oil diplomacy, is the mechanism to build strategic alliances with countries that subscribe to the narrative of solidarity. The crux of the matter is that such a narrative is also related to foreign policy objectives promoted since the restructuration of the Venezuelan political system in the early 2000's. In other words, the actions of SSC in Latin America, the Caribbean and Africa are related to Venezuelan foreign policy goals, both political and economic, such as the construction of a multipolar world, anti-imperialism, anti-capitalism and the fight against neo-liberalism.

It is normally argued that Venezuela's cooperation actions are not oriented towards promoting economic interests. Nevertheless, oil diplomacy also aimed at improving of the Venezuelan influence on production and distribution of energy. The political goals of the Venezuelan SSC initiatives are easier to perceive. Fred Halliday has argued that revolutionary states aimed at exporting at global level the political and economic changes that they have promoted a domestic level [Halliday 1999]. In the Venezuelan case, objectives such as the construction of a multipolar world, a new international balance of power and the reshaping the logic of economic development by rejecting neo-liberalism implied clearly a challenge to the international status quo.

Initiatives such as ALBA, Petrocaribe and the rapprochement to Africa are closely related to the Venezuelan foreign policy objectives. Venezuela aimed at constructing of alliances and coalitions to advance an alternative international agenda. The promotion of new forms of SSC is clearly related to it. Thus, ideas and interests explain the Venezuelan SSC initiatives. On the one hand, Venezuelan SSC aims at promoting the diffusion of a narrative about a model of society promoted by Chávez, through what Forite has called the 'Social Oil Diplomacy' [Forite 2011: 117]. At the same time, the Venezuelan government has used SSC to build alliances to promote its revolutionary foreign policy agenda. Although ideas on solidarity could be influential in the design of the Venezuelan SSC initiatives, interests matter and Realpolitik has definitively played a crucial role in the SSC initiatives towards Latin America, the Caribbean and Africa.

The strategy was successful in terms of showing Venezuela as country that shared the benefits of its economic boom with its partners in the Global South. As a result, Venezuela presence in Latin America, Africa and even the Middle East grew in those years and Chávez became an international figure in the Global South. However, Venezuela was not the only country that developed that strategy in Latin America. Brazil in the Lula da Silva era also fostered program of SSC in Africa and, to a lesser extent, in Latin America. The logic was the same: Realpolitik; Brazilian governments used SSC as a mechanism to promote its country as a global player with influence in Africa and Latin America. The difference was that the anti-imperialist and anti-capitalist rhetoric was absent in the Brazilian documents and discourse on SSC. A second factor that deserves to be considered is that the Venezuelan program was linked to boom in commodities prices, in particular in oil prices. It was due to high oil prices that Venezuela was able to further SSC in Latin America, the Caribbean and Africa. When oil prices fell, SSC initiatives stalled or disappeared. That is the reason why Venezuelan presence in the scenario of SSC in Nicholas Maduro's government is almost non-existent, with the exception maybe of Petrocaribe. 
Venezuela is not actually a newcomer in the arena of SSC, particularly in the Caribbean Basin. Initiatives such the Puerto Ordaz and San José Agreements developed in the 1970's and 1980's are clear manifestations of this commitment to SSC. Nevertheless, the rise to power of Hugo Chávez meant a certain re-signification of SSC that was associated to the new international strategy promoted by so-called 'Bolivarian revolution'. Since the early years of his administration Chávez revisited the cooperation in the field of energy with the Caribbean countries by subscribing the Caracas Energy Agreement in 2000, in which Cuba was incorporated as a partner. Venezuela became rapidly an actor in the SSC. As a result, Caracas promoted initiatives of political, technical and economic cooperation. The Caribbean Basin remained as a major strategic space, expression of what was the creation of Petrocaribe, the flagship of the Venezuelan SSC initiatives. But Caracas' actions went beyond the Caribbean Basin. Argentina, Ecuador, Paraguay received financial assistance. Bolivia, Ecuador participated in social programs such as Yo si Puedo and Misión Milagro. Cooperation in the field of energy was promoted with Uruguay, Ecuador, Bolivia, Argentina and Brazil. Venezuela also actively fostered the setting up of mechanisms of regional dialogue and cooperation such as ALBA, UNASUR and CELAC. Similarly, Africa became a region increasingly more important in the Venezuelan SSC, as manifested by the closer political relations with some African countries, initiatives as the UNASUR-ASA summits and the cooperation in social issues.

This activism was accompanied by a special narrative that stressed different character of the Venezuelan SSC from NSC initiatives. Venezuela emphasized solidarity, complementation, horizontality and equity in its relations with Global South. However, the reality shows that behind that narrative of solidarity, Realpolitik played rather significant role.

The SSC initiatives were used by the Venezuelan administration for promoting the goals of the new foreign policy strategy furthered since the early 2000's. Being a revolutionary state, Venezuela fosters a radical transformation of the international system. This explains why agenda of multipolar world, anti-imperialism and anti-capitalism, the fight against neo-liberalism became the cornerstone of the Venezuelan regional and global strategy. In this respect SSC was treated mainly as a mechanism for reaching those goals. On the one hand, Venezuela's narrative on SSC and the international order demonstrated a soft power approach that aimed to promote the "Bolivarian revolution" as a model of construction of society arguably based on socialist ideas. At the same time, oil diplomacy was the "hard power" instrument for building alliances with countries that shared a similar approach to the world order. In other words, ideational factor mattered significantly in the Venezuelan SSC, but material interests were crucial.

The current political and economic scenario in Venezuela raises doubts about the continuation of the SSC strategy followed in the Chávez era. The internal economic crisis (it is foreseen a 1-million \% inflation for 2018), shortages of basic food and medicaments, violation of human rights, allegations of high-level corruption have significally weakened the image of the 'Chavist revolution'. Moreover, the hard power based on the oil diplomacy has been affected by the reduction of oil prices and more recently due to reduction of the production of PDVSA, the national oil company. 


\section{REFERENCES}

Axelrod, R. (1984). The Evolution of Cooperation. New York: Basic Books Inc., Publishers.

Bagley, B.M. \& Defort, M. (eds.). (2015). Decline of the US Hegemony?: A Challenge of ALBA and a New Latin American Integration of the Twenty-First Century. Lanham, MD: Lexington Books.

Benzi, D. \& Zapata Mafla, X. (2013). Geopolítica, economía y solidaridad internacional en la nueva cooperación sur-sur: el caso de la Venezuela bolivariana y Petrocaribe. América Latina Hoy, $63,65-89$.

Benzi, D. \& Zapata Mafla, X. (2014). Petrolio e petrodollari nella politica internazionale del Venezuela. Una breve rassegna storica (1958-2012). Visioni LatinoAmericane, 1, 63-80.

Benzi, D. (2016). El exitoso ocaso del ALBA: Réquiem para el último vals tercermundista. Nueva Sociedad, 261, 77-91.

Braveboy-Wagner, J.A. (2009). Institutions of the Global South. Abingdon, Oxon: Routledge.

Briceño-Ruiz, J. (2011). El ALBA como propuesta de integración regional. In: ALBA ¿Una nueva forma de integración regional? Ed. by Jossette Altmann Borbón. Buenos Aires: Teseo. p. $19-83$.

Briceño-Ruiz, J. (2011). Los cambios en la Política Exterior de Venezuela y el giro hacia el sur de Chávez. In: La Política Internacional en un mundo en mutación. Ed. by L. Bizzozero, I. Clemente. Montevideo: Ediciones de la Banda Oriental. p. 47-75.

Briceño-Ruiz, J. (2014). El ALBA: una discusión de su modelo, sus resultados y sus perspectivas. Anuario de la Integración Regional de América Latina y el Caribe, 10, 151-178.

Briceño-Ruiz, J. (2015). ¿Gobernanza regional o soft balancing de "Estados revolucionarios"? El discurso y la práctica del ALBA. Pensamiento Propio, 42, 167-194.

Briceño-Ruiz, J. (2006). The Free Trade Area of the Americas in the foreign policy of Hugo Chávez. Unisa Latin American Report, 22 (1), 31-46.

Chávez Frías, H. (2009). Intervención del presidente de la República Bolivariana de Venezuela, Hugo Chávez Frías. In: II Cumbre América Del Sur-África ASA 2009 Cerrando brecha, abriendo oportunidades. Caracas: Colección Cuadernos para el debate, Ministerio del Poder Popular para la Comunicación y la Información.

Clem, R.S. \& Maingot, A.P. (2011). Venezuela's petro-diplomacy: Hugo Chávez's foreign policy. Gainesville: University Press of Florida.

Corrales, J. (2009). Using social power to balance soft power: Venezuela's foreign policy. The Washington Quarterly, 32(4), 97-114.

Dabagyan, E.S. (2012). Foreign Policy of Venezuela at the Beginning of the 21st Century: Key Trends. Moscow University Journal of World Politics, 1, 95-123. (in Russian).

Dabagyan, E.S. (2014). Venezuela after Hugo Chávez. Mirovaya ekonomika i mezhdunarodnye otnosheniya, 7, 67-77. (in Russian).

De Renzio, P. \& Seifert, J. (2014). South-South cooperation and the future of development assistance: mapping actors and options. Third World Quarterly, 35 (10), 1860-1875. DOI: https://doi.org/10.1080/01436597.2014.971603.

Forite, C. (2011). Chávez et l'Afrique. Dix ans de politique extérieure vénézuélienne. Paris: Institut des Hautes Études de l'Amérique latine (IHEAL).

Giacchi, M.F. (2012). La política exterior del gobierno de Hugo Chávez hacia África (2004-2010). Humania del Sur, 7(12), 41-60.

Grayson, G.W. (1985). The San José Oil Facility: South—South Cooperation. Third World Quarterly, 7 (2), 390 - 409. DOI: https://doi.org/10.1080/01436598508419844.

Grieco, J. (1990). Cooperation among Nations: Europe, America, and Nontariff Barriers to Trade. Ithaca: Cornell University Press.

Halliday, Fred. (1999). Revolutions and the World Politics. The rise and fall of the sixth Great Powers. Houndmills and London: Palgrave. 
Hattori, T. (2003). The Moral Politics of Foreign Aid. Review of International Studies, 29 (2), 229-247. DOI: https://doi.org/10.1017/S0260210503002298

Hellinger, D. (2011). Obama and the Bolivarian Agenda for the Americas. Latin American Perspectives, 38 (4), 46 - 62. DOI: https://doi.org/10.1177/0094582X11406209

Jaguaribe, H. (1979). Autonomía periférica y autonomía céntrica. Estudios Internacionales, 12 (46), $91-130$.

Kennan, G. (1971). Foreign Aid as a National Policy. Proceedings of the Academy of Political Science, $30(3), 175-183$.

Keohane, R.O. (1984). After Hegemony. Cooperation and Discord in the World Political Economy. Princeton: Princeton University Press.

Labaqui, I. (2014). Who's afraid of reversing neoliberal reforms? Financial statecraft in Argentina and Venezuela. In: The financial statecraft of emerging powers. Shield and sword in Asia and Latin America. Ed. by L.E. Armijoand, S.N. Katada. Houndmills: Palgrave, p. $21-46$.

Lancaster, C. (2007). Foreign Aid. Diplomacy, Development, Domestic Politics. Chicago and London: The University of Chicago Press.

Lecchini, G. (2012). Reflexiones en torno a la cooperación sur-sur. In: Argentina y Brasil: proyecciones internacionales, Cooperación Sur-Sur e integración. Ed. by C. Morasso, G.P. Doval. Rosario: Editorial de la Universidad Nacional de Rosario, p. 13-26.

Lumsdaine, D.H. (1993). Moral vision in international politics: The foreign aid regime, 1949-1989. Princeton: Princeton University Press.

Maldonado-L. G. (1982). El SELA y la cooperación Sur-Sur. Revista Nueva Sociedad, 60, 39—56.

Mata Carnevali, M.G. (2012a). Relaciones Venezuela-Sudáfrica En el camino de la Cooperación Sur-Sur (2005-2010). Humania del Sur, 7 (13), 155-174.

Mata Carnevali, M.G. (2012b). Venezuela's African Agenda in a South-South Context. The Cases of Algeria, Gambia and South Africa, 2005-2010. Africa Insight, 41 (4), 17-35.

Mawdsley, E. (2011). The changing geographies of foreign aid and development cooperation: contributions from gift theory. Transactions of the Institute of British Geographer, 37, 256-272. DOI: https://doi.org/10.1111/j.1475-5661.2011.00467.x.

Morgenthau, H. (1962). A Political Theory of Foreign Aid. The American Political Science Review, 56 (2), 301-309. DOI: https://doi.org/10.2307/1952366.

Opeskin, B.R. (1996). The Moral Foundations of Foreign Aid. World Development, 24 (1), $21-44$. DOI: https://doi.org/10.1016/0305-750X(95)00118-V.

Pérez, C.A. (1977). La social democracia y las relaciones político económicas internacionales. Revista Nueva Sociedad, 31-32, 5-12.

Pérez, C.A. (1980). El diálogo Norte-Sur. Nueva Sociedad, 51, 33-46.

Pérez, C.A. (1983). El SELA como instrumento político para sus Estados miembros. Nueva Sociedad, $65,45-53$.

Prebisch, R. (1954). International Cooperation in Latin America Development Policy. New York: United Nations.

Prebisch, R. (1969). Reflexiones sobre la cooperación internacional en el desarrollo latinoamericano. Comercio Exterior, 19 (10), 758-766.

Puig, J.C. (1980). Doctrinas internacionales y Autonomía latinoamericana. Caracas: Universidad Simón Bolívar, Instituto de Altos Estudios de América Latina.

Romero, C.A. (2003). Dos etapas en la política exterior de Venezuela. Politeia, 30, 319-343.

Romero, C.A. (2010). La política exterior de la Venezuela bolivariana. URL: http://www.plataformademocratica.org/arquivos/la\%20politica\%20exterior\%20de\%201a $\% 20$ venezuela\%20bolivariana.pdf (accessed 12.06.2018).

Romero, C.A. \& Curiel, C. (2009). Venezuela: política exterior y rentismo. Cadernos Prolam/USP, 8(14), 39-61. DOI: https://doi.org/10.11606/issn.1676-6288.prolam.2009.82330.

Romero, C.A. \& Mijares, V.M. (2016). From Chávez to Maduro: Continuity and Change in Venezuelan Foreign Policy. Contexto Internacional, 38 (1), 165-201. DOI: http://dx.doi.org/10.1590/ S0102-8529.2016380100005. 
Ruttan, V.W. (1989). Why Foreign Economic Assistance? Economic Development and Cultural Change, 37(2), 411-424. DOI: 10.1086/451730.

Salazar Santos, F. (1985). El SELA: Antecedentes y realizaciones. Integración Latinoamericana, 10 (107), 3-27.

Serbin, A. \& Serbin Pont, A. (2014). Quince años de política exterior bolivariana: ¿entre el softbalancing y la militarización? Pensamiento Propio, 19 (39), 287-326.

Revised Guidelines for the Review of Policies and Procedures Concerning Technical Cooperation among Developing Countries. TCDC/13/3. (2003). United Nations — Technical Cooperation Among Developing Countries. New York: United Nations.

What is South-South Cooperation. (2015). UNOSSC — United Nations Office for South South Cooperation. URL: http://ssc.undp.org/content/ssc/about/what_is_ssc.html (accessed 02.04.2015).

Younas, J. (2008). Motivation for bilateral aid allocation: Altruism or trade benefits. European Journal of Political Economy, 24, 661 — 674. DOI: https://doi.org/10.1016/j.ejpoleco.2008.05.003.

Received: 15.08 .2018

For citations: Briceño-Ruiz, J. (2018). South-South Cooperation in the Chávez Era in Venezuela. Vestnik RUDN. International Relations, 18 (3), 479-496. DOI: 10.22363/2313-0660-2018-183-479-496.

About the Author: José Briceño-Ruiz — PhD in Political Science, Professor at the Universidad Cooperativa de Colombia, Bogotá (e-mail: bricenoruiz@hotmail.com).

DOI: $10.22363 / 2313-0660-2018-18-3-479-496$

\title{
ВЕНЕСУЭЛА В ЭПОХУ УГО ЧАВЕСА И СОТРУДНИЧЕСТВО ПО ЛИНИИ ЮГ-ЮГ
}

\author{
Х. Брисеньо-Руиз \\ Кооперативный университет Колумбии, Богота, Колумбия
}

\begin{abstract}
Одним из ключевых трендов международных отношениях нового тысячелетия стало сотрудничество Юг-Юг. Инициативы политического сотрудничества, предоставления экономической и технической помощи в этом направлении можно проследить с 1960-х гг., например, в рамках Бандунгской конференции неприсоединившихся стран или по линии создания Конференции Организации Объединенных Наций по торговле и развитию (ЮНКТАД) под эгидой Рауля Пребиша [Braveboy-Wagner 2009; Prebisch 1954, 1969]. Последовавшее возвышение Китая и БРИКС и новый период высоких цен на нефть привели к увеличению доли участия стран со средним уровнем доходов в сотрудничестве с другими странами Глобального Юга.

В период президентства Уго Чавеса Венесуэла активно участвовала в рамках сотрудничества Юг-Юг. Разумеется, данное направление не является полностью новаторским во внешней политике Венесуэлы. Начиная с 1970-х гг. Каракас поступательно реализовывал программы сотрудничества по поставке нефти на особых условиях в некоторые страны Центральной Америки и Карибского бассейна. В качестве примеров выступают Соглашение в Пуэрто-Ордасе, подписанное во время правления Карлоса Андреса Переса (1974-1979 гг.), и Соглашение Сан-Хосе, венесуэльско-мексиканская инициатива, запущенная в начале 1980-х гг. [Grayson 1985]. Карлос Андрес Перес, используя аналогичные методы и стратегию, оказал значимое влияние на продвижение нового международного экономического порядка и создание Латиноамериканской экономической системы (известной на испанском языке как SELA) [Pérez 1980, 1983].
\end{abstract}


Однако логика участия Венесуэлы в сотрудничестве по линии Юг-Юг изменилась именно после прихода к власти У. Чавеса в 1999 г. и, в частности, после его победы на референдуме в 2004 г. С самого начала своего президентства Чавес стремился преобразовать внешнюю политику Венесуэлы. Одной из его целей было существенное углубление сотрудничества с Глобальным Югом. Венесуэла как страна со средним доходом стала своего рода локомотивом в новой динамике сотрудничества Юг-Юг как в Латинской Америке и Карибском бассейне, так и за пределами Западного полушария.

В данной статье анализируется все более активное участие Венесуэлы в инициативах по линии Юг-Юг, в частности, причины подобной активизации в рамках правления У. Чавеса. На фоне активного использования венесуэльским правительством особой риторики в вопросах диалога Юг-Юг с опорой на принципы солидарности, взаимодополняемости и сотрудничества, автор сравнивает стратегию международного сотрудничества Венесуэлы с более традиционными формами сотрудничества по линии Север-Юг. Для достижения поставленной цели в статье используются качественные методы анализа, включающие анализ литературы по международному сотрудничеству с позиций разных теоретических подходов и оценку международного сотрудничества, проводимого правительством Венесуэлы.

Ключевые слова: сотрудничество Юг-Юг, Уго Чавес, Венесуэла, «Боливарианская революция», нефтяная дипломатия

\section{БИБЛИОГРАФИЧЕСКИЙ СПИСОК}

Дабагян Э.С. Венесуэла после Уго Чавеса // Мировая экономика и международные отношения. 2014. № 7. С. $67-77$.

Дабагян Э.С. Внешняя политика Венесуэлы в начале XXI в.: основные направления // Вестник Московского университета. Сер. 25. Международные отношения и мировая политика. 2012. № 1. C. $95-123$.

Axelrod R. The Evolution of Cooperation. New York: Basic Books Inc., Publishers, 1984.

Decline of the US Hegemony?: A Challenge of ALBA and a New Latin American Integration of the Twenty-First Century / ed. by Bagley B.M., Defort M. Lanham, MD: Lexington Books, 2015.

Benzi D., Zapata Mafla X. Geopolítica, economía y solidaridad internacional en la nueva cooperación sur-sur: el caso de la Venezuela bolivariana y Petrocaribe // América Latina Hoy. 2013. N 63. P. $65-89$.

Benzi D., Zapata Mafla X. Petrolio e petrodollari nella politica internazionale del Venezuela. Una breve rassegna storica (1958-2012) // Visioni LatinoAmericane. 2014. N 1. P. 63-80.

Benzi D. El exitoso ocaso del ALBA: Réquiem para el último vals tercermundista // Nueva Sociedad. 2016. N 261. P. 77-91.

Braveboy-Wagner J.A. Institutions of the Global South. Abingdon, Oxon: Routledge, 2009.

Briceño-Ruiz J. El ALBA como propuesta de integración regional // ALBA ¿Una nueva forma de integración regional? / ed. by Jossette Altmann Borbón. Buenos Aires: Teseo, 2011. P. 19-83.

Briceño-Ruiz J. Los cambios en la Política Exterior de Venezuela y el giro hacia el sur de Chávez // La Política Internacional en un mundo en mutación / ed. by L. Bizzozero, I. Clemente. Montevideo: Ediciones de la Banda Oriental, 2011. P. 47-75.

Briceño Ruiz J. El ALBA: una discusión de su modelo, sus resultados y sus perspectivas. Anuario de la Integración Regional de América Latina y el Caribe. 2014. N 10. P. 151-178.

Briceño-Ruiz J. ¿Gobernanza regional o soft balancing de "Estados revolucionarios"? El discurso y la práctica del ALBA // Pensamiento Propio. 2015. N 42. P. 167-194.

Briceño-Ruiz J. The Free Trade Area of the Americas in the foreign policy of Hugo Chávez // Unisa Latin American Report. 2006. Vol. 22. N 1. P. 31- 46.

Chávez Frías H. Intervención del presidente de la República Bolivariana de Venezuela, Hugo Chávez Frías // II Cumbre América Del Sur-África ASA 2009 Cerrando brecha, abriendo oportunidades. Caracas: Colección Cuadernos para el debate, Ministerio del Poder Popular para la Comunicación y la Información, 2009. 
Clem R.S., Maingot A.P. Venezuela's petro-diplomacy: Hugo Chávez's foreign policy. Gainesville: University Press of Florida, 2011.

Corrales $J$. Using social power to balance soft power: Venezuela's foreign policy // The Washington Quarterly. 2009. Vol. 32. N 4. P. 97-114.

De Renzio P., Seifert J. South-South cooperation and the future of development assistance: mapping actors and options // Third World Quarterly. 2014. Vol. 35. N 10. P. 1860-1875. DOI: https://doi.org/10.1080/01436597.2014.971603.

Forite $C$. Chávez et l'Afrique. Dix ans de politique extérieure vénézuélienne. Paris: Institut des Hautes Études de l'Amérique latine(IHEAL), 2011.

Giacchi M.F. La política exterior del gobierno de Hugo Chávez hacia África (2004-2010) // Humania del Sur. 2012. Vol. 7. N 12. P. 41-60.

Grayson G.W. The San José Oil Facility: South—South Cooperation // Third World Quarterly. 1985. Vol. 7. N 2. P. 390 - 409. DOI: https://doi.org/10.1080/01436598508419844.

Grieco J. Cooperation among Nations: Europe, America, and Nontariff Barriers to Trade. Ithaca: Cornell University Press, 1990.

Halliday Fred. Revolutions and the World Politics. The rise and fall of the sixth Great Powers. Houndmills and London: Palgrave, 1999.

Hattori T. The Moral Politics of Foreign Aid // Review of International Studies. 2003. Vol. 29. N 2. P. 229-247. DOI: https://doi.org/10.1017/S0260210503002298.

Hellinger D. Obama and the Bolivarian Agenda for the Americas // Latin American Perspectives. 2011. Vol. 38. N 4. P. 46-62. DOI: https://doi.org/10.1177/0094582X11406209.

Jaguaribe H. Autonomía periférica y autonomía céntrica // Estudios Internacionales. 1979. Vol. 12. N 46. P. 91-130.

Kennan G. Foreign Aid as a National Policy // Proceedings of the Academy of Political Science. 1971. Vol. 30. N 3. P. 175-183.

Keohane R.O. After Hegemony. Cooperation and Discord in the World Political Economy. Princeton: Princeton University Press, 1984.

Labaqui I. Who's afraid of reversing neoliberal reforms? Financial statecraft in Argentina and Venezuela // The financial statecraft of emerging powers. Shield and sword in Asia and Latin America / ed. by L.E. Armijoand, S.N. Katada. Houndmills: Palgrave, 2014. P. $21-46$.

Lancaster C. Foreign Aid. Diplomacy, Development, Domestic Politics. Chicago and London: The University of Chicago Press, 2007.

Lecchini $G$. Reflexiones en torno a la cooperación sur-sur // Argentina y Brasil: proyecciones internacionales, Cooperación Sur-Sur e integración / ed. by C. Morasso, G.P. Doval. Rosario: Editorial de la Universidad Nacional de Rosario, 2012. P. 13-26.

Lumsdaine D.H. Moral vision in international politics: The foreign aid regime, 1949-1989. Princeton: Princeton University Press, 1993.

Maldonado-L. G. El SELA y la cooperación Sur-Sur // Nueva Sociedad. 1982. N 60. P. 39-56.

Mata Carnevali M.G. Relaciones Venezuela-Sudáfrica En el camino de la Cooperación Sur-Sur (2005-2010) // Humania del Sur. 2012a. Vol. 7. N 13. P. 155-174.

Mata Carnevali M.G. Venezuela's African Agenda in a South-South Context. The Cases of Algeria, Gambia and South Africa, 2005-2010 // Africa Insight. 2012b. Vol. 41. N 4. P. 17-35.

Mawdsley E. The changing geographies of foreign aid and development cooperation: contributions from gift theory. Transactions of the Institute of British Geographer. 2011. N 37. P. 256-272. DOI: https://doi.org/10.1111/j.1475-5661.2011.00467.x.

Morgenthau H. A Political Theory of Foreign Aid // The American Political Science Review. 1962. Vol. 56. N 2. P. 301-309. DOI: https://doi.org/10.2307/1952366.

Opeskin B.R. The Moral Foundations of Foreign Aid // World Development. 1996. Vol. 24. N 1. P. 21 - 44. DOI: https://doi.org/10.1016/0305-750X(95)00118-V.

Pérez C.A. La social democracia y las relaciones político económicas internacionales // Revista Nueva Sociedad. 1977. N 31-32. P. 5-12. 
Pérez C.A. El diálogo Norte-Sur// Nueva Sociedad. 1980. N 51. P. $33-46$.

Pérez C.A. El SELA como instrumento político para sus Estados miembros // Nueva Sociedad. 1983.

N 65. P. 45-53.

Prebisch R. International Cooperation in Latin America Development Policy. New York: United Nations, 1954.

Prebisch R. Reflexiones sobre la cooperación internacional en el desarrollo latinoamericano // Comercio Exterior. 1969. Vol. 19. N 10. P. 758-766.

Puig J.C. Doctrinas internacionales y Autonomía latinoamericana. Caracas: Universidad Simón

Bolívar, Instituto de Altos Estudios de América Latina, 1980.

Romero C.A. Dos etapas en la política exterior de Venezuela // Politeia. 2003. N 30. P. 319—343.

Romero C.A. La política exterior de la Venezuela bolivariana. 2010. URL: http://www.plataformademocratica.org/arquivos/la $\% 20$ politica $\% 20$ exterior $\% 20 \mathrm{de} \% 201 \mathrm{la} \% 20$ venezuela\%20bolivariana.pdf (accessed 12.06.2018).

Romero C.A., Curiel C. Venezuela: política exterior y rentismo // Cadernos Prolam/USP. 2009. Vol. 8. N 14. P. 39-61. DOI: https://doi.org/10.11606/issn.1676-6288.prolam.2009.82330.

Romero C.A., Mijares V.M. From Chávez to Maduro: Continuity and Change in Venezuelan Foreign Policy // Contexto internacional. 2016. Vol. 38. N 1. P. 165-201. DOI: http://dx.doi.org/ 10.1590/S0102-8529.2016380100005.

Ruttan V.W. Why Foreign Economic Assistance? // Economic Development and Cultural Change. Vol. 37. N 2. P. 411-424. DOI: 10.1086/451730.

Salazar Santos F. El SELA: Antecedentes y realizaciones // Integración Latinoamericana. 1985. Vol. 10. N 107. P. 3-27.

Serbin A., Serbin Pont A. Quince años de política exterior bolivariana: ¿entre el soft-balancing y la militarización? // Pensamiento Propio. 2014. Vol. 19. N 39. P. 287-326.

Revised Guidelines for the Review of Policies and Procedures Concerning Technical Cooperation among Developing Countries. TCDC/13/3. United Nations - Technical Cooperation Among Developing Countries. New York: United Nations, 2003.

What is South-South Cooperation. UNOSSC - United Nations Office for South South Cooperation. 2015. URL: http://ssc.undp.org/content/ssc/about/what_is_ssc.html (accessed 02.04.2015).

Younas J. Motivation for bilateral aid allocation: Altruism or trade benefits // European Journal of Political Economy. 2008. N 24. P. 661 — 674. DOI: https://doi.org/10.1016/j.ejpoleco.2008.05.003.

Дата поступления статьи: 15.08.2018

Для цитирования: Briceño-Ruiz J. South-South Cooperation in the Chávez Era in Venezuela // Вестник Российского университета дружбы народов. Серия: Международные отношения. 2018. T. 18. № 3. C. 479 - 496. DOI: 10.22363/2313-0660-2018-18-3-479-496.

Сведения об авторе: Хосе Брисеньо-Руиз - доктор политических наук, профессор Колумбийского кооперативного университета, Богота, Колумбия (e-mail: bricenoruiz@hotmail.com). 